Loebeck, M. E. \& Ordal, E. J. (1957). J. gen. Microbiol. 16, 76-85

\title{
The Nuclear Cycle of Myxococcus fulvus
}

\author{
By MAUDE E. LOEBECK* AND E. J. ORDAL \\ The Department of Microbiology, University of Washington, \\ Seattle, Washington, U.S.A.
}

SUMMARY: The life cycle of Myxococcus fulvus consists of the following stages: germinating microcysts, young vegetative cells, intermediate cells, mature cells and resting microcysts. Germination takes place by simple elongation, or germ-tube formation. The nucleus of the germinating microcyst is a single oval or elongate body. The young vegetative cell should probably be referred to as multinucleate because the nucleus consists of a string of lobate bodies. In intermediate and mature cells the nucleus is either bi-lobed or oval, with the presence of entire edges. Details of the electron micrographs suggest a nuclear membrane. Microcysts normally have a single nucleus, and possibly possess nucleoli. Resting microcysts consist of a thin outer shell, a thick inner shell, cytoplasm and a nucleus.

In studying the cytology of Myxococcus virescens Badian (1930) presented evidence of the presence of discrete chromatinic bodies, interpreted as nuclei, in vegetative cells of this myxobacterium. Beebe (1941), studying the cytology of $M$. xanthus, reported the presence of nuclear structures clearly analogous to those observed by Badian (1930). Complex nuclear cycles were postulated by Badian and by Beebe. These hardly seem justified, however, on the basis of the evidence presented. Three species of terrestrial myxobacteria were studied by Klieneberger-Nobel (1947) who used mainly the acid Giemsa method of Robinow (1944). These included $M$. fulvus, M. virescens and Chondrococcus exiguus. Young vegetative cells were reported to contain two transverse nuclear structures which divided lengthwise into four before cell-division occurred. When a culture became well established, a new development occurred in some of the cells. The two nuclear structures in each cell increased in size but did not divide. Each cell now shortened and became round with the simultaneous fusion of the two nuclear elements first into a rod-like and eventually into a round chromatinic body. This cell was called a 'fusion cell'. According to Klieneberger-Nobel, the fusion cell now enlarged and stretched to an oval form. At the same time the nuclear body of the fusion cell elongated into a rod or dumbbell-like structure which divided into two (or four) nuclear elements. Subsequently, the cell again rounded up and became smaller, developing into a microcyst with a tough dense outer layer.

In this laboratory it was found that the nucleus of Myxococcus fulvus could often be demonstrated with the electron microscope in whole untreated cells. The present investigation is a study of the nuclear cycle in M. fulvus using light and electron microscopy.

* Present address : Roswell Park Memorial Institute, Buffalo 3, New York. 


\section{ME'THODS}

Myxococcus fulvus, University of Washington strain M6, was used in this investigation. This strain was selected for cytological study, from a number of well-defined strains of $\boldsymbol{M}$. fulvus isolated in this laboratory, for several reasons. Slime was formed in relatively small amounts as compared to most strains, and hence there was little interference with the fixation and staining of habit patterns. Furthermore, strain M6 was able to form fruiting bodies when the amount of nutrient material was decreased to a very low concentration. Under these circumstances the fruiting bodies were so small that they could be removed intact by the agar block technique.

A dung decoction agar medium was used for the cytological studies. This medium was prepared in the following manner. A dung extract was prepared by boiling 1 vol. of rabbit dung with 2 vol. of water for $10 \mathrm{~min}$. The supernatant fluid was removed, autoclaved and added in a concentration of $5 \%(w / v)$ to sterile $1.5 \%(\mathrm{w} / \mathrm{v})$ water agar. To this was added $1 \%(\mathrm{w} / \mathrm{v})$ of a heavy suspension of heat-killed bacteria consisting of equal portions of Escherichia coli and Proteus vulgaris. Stock cultures of Myxococcus fulvus were maintained on $1 \%$ water agar overlaid with a heavy suspension of autoclaved $E$. coli.

For the study of nuclear structures by light microscopy, impression films were prepared by the $\mathrm{OsO}_{4}$-Giemsa method of Robinow (1947). Entire colonies or any portion thereof could be stained in this manner.

For electron microscopy Myxococcus fulvus was grown on collodion or formvar films. Collodion films were prepared directly on the surface of the dung decoction agar medium following the method of Hillier, Knaysi \& Baker (1948). Small squares were cut from the agar at the desired location in the colony and the film floated off in water. Some of the preparations were fixed by exposure to $\mathrm{OsO}_{4}$ vapours for 2 or $3 \mathrm{~min}$. The formvar films were prepared in the same manner as the collodion films, except that chilled Ringer's solution was used instead of distilled water to cover the agar surface. The subsequent treatment was the same as with collodion film.

Material for ultra-thin sections was prepared according to the method of Chapman \& Hillier (1953). The sections were cut on a Spencer rotary microtome equipped to cut thin sections by thermal expansion.

Electron microscopy was performed with the RCA electron microscope Model EMU-2B. Photomicrographs were taken with a Leitz microscope with a combination of a $\times 92,2 \mathrm{~mm}$. apochromatic objective and a $\times 15$ compensating ocular and a Bausch and Lomb type $\mathbf{R}$ camera. Eastman M plates were used.

\section{RESULTS}

\section{The myxobacterial colony}

The creeping motility of terrestrial fruiting myxobacteria determines the morphology of the colony. The vegetative cells, instead of piling up as do most eubacteria, move outward over the surface of the agar, forming a very thin film which is often only one layer of cells in thickness. Fruiting-body production 
first begins at or near the point of inoculation and then extends outward in the colony, the fruiting bodies usually appearing in concentric rings around the central portion of the colony.

Three regions were found in the colony of Myxococcus fulvus. These three regions are evident by macroscopic appearance, and the cells in these regions are so characteristic that one can tell from which region they came by examination of the nuclear material. The first region is at the periphery of the colony and contains rapidly proliferating vegetative cells which have access to fresh nutriment. This region is very narrow, even in large colonies not more than about 1-2 mm. wide. It has more cells/unit area than any region except for the fruiting body. Because of this, it has a delicate raised appearance.

The second region lies behind the first region, in which active multiplication of cells is occurring. Radial ridges and concentric rings of slime are characteristically observed in this region. This may be the result of the secretion of slime by the generations of passing cells and the grouping of the cells left behind. The cells in the second region, however, are present for the most part as a monolayer. The most typical cells are long and slender, and on drying shows a marked constriction near the middle. The cells in this region are called intermediate cells because of their age and position in the colony.

The third region is the area of fruiting body production and represents the oldest part of the colony. As the cells age they gather to form the fruiting bodies. With the passing of time the intermediate areas are practically cleared of cells except for areas of fruiting. The concentric rings now become concentric rings of fruiting bodies. Microcysts can be found abundantly within the fruiting bodies and in some cases adjacent to the fruiting bodies.

\section{The life cycle}

Germination. Mature microcysts of Myxococcus fulvus, strain M6, remained undifferentiated when stained by the Robinow-Giemsa method. When placed on nutrient medium, they began to germinate in $c .3 \mathrm{hr}$. and at this time showed a single chromatinic structure which was usually round and excentric though sometimes centrally located. As the cells began to elongate, the chromatinic body, or nucleus, most frequently appeared as a transverse band. In some cases the elongation took the form of a narrow tube, which in some individuals resembled the germination tube described in some yeasts. It is of interest to note that Kunicki-Goldfinger (1949) observed the formation of germ tubes during the germination of microcysts from a species of Sporocytophaga. As the cell continued to elongate, the transverse chromatin band appeared to rotate to a longitudinal position. When a cell produced a germ tube, the chromatinic body often appeared at the junction, distributed between the two portions. Some cells resembled a bowling pin with the chromatinic body at the neck. As the cells elongated further, the nuclear material divided into an irregular number of masses as indicated by nuclear stains (Pl. 1, fig. 1).

When germinating microcysts were stained with Sudan black in ethyleneglycol, granules taking the Sudan stain were normally found at or near one or both ends of the elongating cells. When the column of the electron microscope 
was evacuated, holes often developed in the regions of the cells corresponding to those which stained with Sudan black. The holes became more obvious when the preparations were shadowed and, as shown in Pl. 1, fig. 2, the cells were often torn and distorted. Holes did not appear in preparations of germinating microcysts fixed with $\mathrm{OsO}_{4}$. In view of the staining behaviour with Sudan black and volatilization in the electron microscope, it seems likely that the granules are lipid in character.

Nuclei were not demonstrable in preparations of germinating microcysts under the electron microscope. However, small electron-dense granules were often found in cells of lesser opacity.

Young vegetative cells. The swarm cell of the advancing front in the first region of the colony had a characteristic appearance. With development of the germinating microcyst into the vegetative cell the lipid-like droplets or granules diminished in size and disappeared. Giemsa stains of swarm cells are shown in $\mathrm{Pl}$. 1, fig. 3. The ends of the cells were devoid of chromatinic material. The central portion of the cell was quite well filled by a number of irregular masses of chromatin, apparently attached to each other by chromatinic threads. In electron micrographs, cells from the advancing front were differentiated into relatively transparent and opaque areas (cf. Pl. 1, fig. 4). The ends of the cells were quite dense, representing the cytoplasm. More of this dense formless material, which must also be cytoplasm, was scattered throughout the cells.

Intermediate cells. The intermediate cells of Myxococcus fulvus left behind by the advancing frontal wave were long and slender. A Giemsa preparation of such cells is shown in Pl. 2, fig. 5. The clear cytoplasmic areas at each end were longer than in the younger cells, and the edges of the nuclei are entire. The nucleus was long and filled the entire width of the cell. There was sometimes a constriction in the cell membrane near the centre of the cell, and the bi-lobed nucleus, which occupied a central position, also had the constriction. The constriction of the membrane may be an artefact produced by drying since it is not visible in the living cells. These may be the cells which Klieneberger-Nobel (1947) called 'fusion cells', because she considered that two nuclei were fusing. Since there is at present no method of demonstrating multi-cellularity in myxobacteria, it was not possible to determine whether this cell was dividing or whether the nuclear material was fusing.

When the cells of the intermediate region were studied by electron microscopy, it was found that the densities of the nuclear and cytoplasmic material were sometimes reversed, though the two types never appeared in the same preparation. The most frequent form was the one in which the cytoplasm appeared more dense than the nucleus; such cells are shown in Pl. 2, fig. 6, and Pl. 2, fig. 7. On some occasions the reverse was true, and the nucleus appeared quite dense; Pl. 2, fig. 8, shows this type of cell. Small dense granules, apparently intranuclear, were sometimes observed (cf. Pl. 2, fig. 7). Similar granules were observed at other stages of development, and these are hereafter referred to as organelles.

Mature cells. As judged by light microscopy, the mature cells of Myxococcus fulvus, just before encystment, were much shortened and appeared to have 
a single nucleus, centrally located, which occupied a major portion of the cell. Giemsa stains of mature cells are shown in Pl. 3, fig. 9; electron micrographs in Pl. 3, figs. 10 and 11. The stained cells looked relatively uniform. In the Giemsa preparations the nucleus was oval and the cytoplasm seemed to shrink, possibly because of hydrolysis. This left the impression that the nucleus had a larger diameter than the rest of the cell, but this may have been due to halation.

The electron micrographs of mature cells showed much more variation. The less dense nuclei (Pl. 3. fig. 11) were seen most frequently. The cells were shortened and the nucleus appeared as a single structure. In many cases small dense granules or organelles were again seen.

The more dense nuclei were less common and are shown in Pl. 3, fig. 10. The presence of organelles was very striking. As a general rule, these structures were confined to the nucleus. In some instances they appeared to be extruded from the nucleus or from the cell. The fact that they appeared in both the dense and light nuclei, lent support to the belief that the light and dark nuclei were indeed identical structures.

When the cells rounded up, they appeared by the Giemsa stain to be almost entirely nuclear material. The oval cells in Pl. 3, fig. 9, are comparable to the shortened broad cell in Pl. 3, fig. 10. The nucleus was found along one side. It seems likely that when hydrolysed and impregnated with stain, the nearly round cells (Pl. 3, figs. 11, 12) would appear entirely stained since the narrow shrunken cytoplasm would doubtless be beyond the resolution of the light microscope. When cells of this type were shadowed they appeared flattened (Pl. 4, fig. 13). The mature microcyst was found to be a sphere, not subject to flattening, or differential staining, and casting a long oval shadow (Pl. 4, fig. 14).

As with other organisms, old cultures of myxobacteria have "involution forms'. Although these cells appear in some of the photographs no effort is made to describe them.

Microcysts. Intact normal microcysts revealed no internal structure when studied by ordinary hydrolysis followed by staining, or by electron microscopy. By subjecting microcysts to disintegration and by the study of ultra-thin sections, evidence was obtained that microcysts consist of a thin outer shell or coat, a thick inner shell, cytoplasm and nucleus.

Suspensions of microcysts were placed in the Mickle disintegrator for a total period of 30 min.; at 5 min. intervals samples were removed, fixed with $\mathrm{OsO}_{4}$ and examined with the electron microscope. One cell in Pl. 4, fig. 15, shows the outer shell cracked but still encircling the core. A cell with an intact inner shell is shown in the same figure. Free outer shells, shadowed with nickel (Pl. 4, fig. 16) had much the same appearance as cell walls of eubacteria. When the inner shell was ruptured, as shown in Pl. 4, fig. 17, it appeared to have a firm consistency as suggested by the appearance of torn edges. In some of the cells shown in Pl. 4, fig. 17, the material on the inside of the inner shell had evidently been extruded and disintegrated.

Ultra-thin sections of microcysts are shown in Pl. 5, figs. 18 and 19. During manipulation, it was not uncommon for the outer shell to become detached 
from the sectioned microcysts; hence this structure was not clearly apparent in all cells. The inner shell was very opaque and in most cases clearly distinguishable. As in germinating microcysts, there was evidence of the occurrence of lipid within or below the second shell.

A soft extrudable core was found inside the inner shell. Since no stains were made of the ultra-thin sections, their staining properties are not known. From studies on germination, however, it is logical to assume that the less dense material is nuclear in nature. This is in keeping with the density relationships observed in most cells in which relatively transparent nuclei and opaque cytoplasm were found. As in intermediate cells and mature cells, organelles were present which appear to be intranuclear.

\section{DISCUSSION}

In the typical vegetative or swarm cell the nuclear bodies increase to $2,3,4$ or more masses. They are irregular in number and shape and appear to be connected by chromatinic threads. The polar areas are normally devoid of nuclear material. The electron micrographs confirm this picture. The cytoplasmic polar caps are entirely dark, and scattered throughout the central area is more dense material which must also be cytoplasmic in nature. The light areas, interspacing the dense material, appear as lobate masses, connected in a string and often lying on one side of the cell. These findings are much like those obtained by Chapman \& Hillier (1953) in ultra-thin sections of vegetative Bacillus cereus in which the nuclei consisted of a series of swollen structures connected with constricted portions of the same material which were reported to be 'not necessarily axial'.

A number of investigators have attached importance to the number of chromatinic bodies which appear in bacteria (Robinow, 1947; KlienébergerNobel, 1945; Bisset, 1950; Grace, 1951; Fitz-James, 1954). KlienebergerNobel (1947) emphasized the occurrence of two to four chromatinic bodies in cells in preparations of young myxobacteria. Fitz-James (1954) followed the changes in the chromatinic bodies of Bacillus cereus from the resting cell to the first division and claimed to have found a constant number which duplicated. The general impression with Myxococcus fulvus, however, is that there is great irregularity in the number of chromatinic bodies.

The transparency of the bacterial nucleus to the electron beam has been a controversial issue. It has been reported to be more transparent than the cytoplasm (Cosslett, 1948; Robinow \& Cosslett, 1948; Hillier, Mudd \& Smith, 1949), or to consist of a dense matrix (Piekarski, 1939; Knaysi \& Mudd, 1943; Knaysi, Hillier \& Fabricant, 1950). The density of the nucleus reported here cannot be attributed to or correlated with the treatment to which the organism has been subjected. The dark nuclei were found in the cells grown on collodion and formvar films, and directly on dung agar, but never with fixed specimens. Light nuclei appeared in unfixed cells grown on collodion and formvar films and on cells grown on formvar film and fixed with $\mathrm{OsO}_{4}$. The cells were all grown on dung agar, and various lots of dung agar, even though made by the 
same formula, may vary. Knaysi (1951) showed that the omission of a nitrogen supply caused an increase in the transparency of the cytoplasm in Bacillus megaterium. It is difficult to believe, however, that the nitrogen supply could vary to this extent with the dung agar medium.

Small dense bodies, or organelles, were found at all stages of development of Myxococcus fulvus except during the period of active multiplication. These organelles appeared to be primarily intranuclear. While their nature is not known, it is tempting to consider that they are nucleoli. To the best of our knowledge, with one possible exception (Knaysi et al. 1950), structures exactly like the organelles shown in Pl. 1, fig. 2; Pl. 2, fig. 7; Pl. 3, figs. 10 and 12 have not been described in other bacteria. Large electron-dense bodies were found by Knaysi et al. (1950) in an avian strain of Mycobacterium. These were located chiefly near the ends of the cells and were considered to be nuclei. Small nearly spherical dense structures were found, however, by these investigators in transparent bodies which were considered to be cell sap vacuoles. Electrondense bodies found in mycobacteria by Winterscheid \& Mudd (1953) were identified as mitochondria. Nuclei were considered to be less dense than the cytoplasm and to be located between the electron dense bodies. Structures analogous to the cell sap vacuoles were not resolved.

Brieger, Cosslett \& Glauert (1954) studied the reproductive changes in strains of avian tubercle bacilli and concluded that the large electron-dense bodies were not nuclei. These investigators reported the formation of discrete intracellular units inside elongating filaments of tubercle bacilli. Subsequently massive production of small rods occurred. Although details of the transformation from filaments to short rods were not observed, it was suggested that processes such as division by retraction or liberation of intracellular units must be considered in addition to transverse fission. Transparent bodies, referred to as vacuolized structures, each with a limiting membrane, were observed in many preparations, and it was noted that they had a location similar to that of the intracellular units. The question was raised as to whether the intracellular units, which developed into rods, and the transparent bodies were independent structures or were the same structures in different stages of development. No mention was made of the occurrence of small dense granules within the transparent structures as observed by Knaysi et al. (1950). Further evidence against the hypothesis that the large electron-dense bodies are nuclei was provided by Glauert \& Brieger (1955) in a study on Mycobacterium phlei. The dense bodies were found to contain metaphosphates and to show metachromasia. The possibility that they might be mitochondria was discounted. According to Glauert \& Brieger (1955) there is still uncertainty as to the location of the nucleus in mycobacteria. If the large electron-dense bodies are not nuclei, is it possible that the structures referred to as cell sap vacuoles or transparent bodies are nuclei? From the studies of KlienebergerNobel (1945) and Delaporte (1950) it is evident that the chromatinic masses in Bacillus and Clostridium may be quite numerous, and other masses may be below the limit of resolution of the light microscope. Therefore, the number of a few to twenty cell sap vacuoles reported by Knaysi et al. (1950) may not 
be unreasonable for nuclear material. If indeed these cells are multicellular as Bisset (1953) stated, no statement can be made about the number of vacuoles/cell until the number of cross-walls is determined. The cross-walls do not show in electron micrographs of Mycobacterium without special treatment (Bisset, 1953). If these vacuoles should be nuclear, then the small dense organelles found by Knaysi et al. (1950) in mycobacteria would be intranuclear and would have the same relationship to these cells as the organelles of myxobacteria.

Germinating microcysts of Myxococcus fulvus show the organelles when no nuclear structures are visible (cf. Pl. 1, fig. 2). If at other stages of development these organelles are associated with the nucleus, then it is possible at this stage also. The thickness of organisms, either eubacterial or myxobacterial, may prevent the detection of a relatively transparent nucleus, but the dense organelles may still be seen. The electron-dense structures in mycobacteria and other bacteria which Mudd (1953) considered to be mitochondria had the following dimensions: Mycobacterium spp. $2 \cdot 0 \times 0.5 \mu$. with spherules 0.02-0.05 $\mu$.; Corynebacterium spp. 0.7-0.1 $\mu$. or less; Escherichia coli lysed by phage $0 \cdot 4-0 \cdot 2 \mu$; Micrococcus cryophilus $0 \cdot 2-0 \cdot 1 \mu$. The organelles occurring in Myxococcus fulvus are of the range of $0 \cdot 05-0 \cdot 10 \mu$. Their presence in the nucleus or on the nuclear membrane indicates that these structures in $\boldsymbol{M}$. fulvus are not mitochondria.

The observations reported here lend support to the hypothesis that the nucleus in Myxococcus fulvus is surrounded at all times by a nuclear membrane. In young rapidly growing cells, karyokinesis is far in advance of cytokinesis; therefore the nuclear apparatus in these cells is very irregular and shows much lobation and many strictures. Hence little importance can be attached to the number of chromatinic bodies present in a given cell. The above hypothesis does not require a separate interpretation for eubacteria, since it is in keeping with the observations of Chapman \& Hillier (1953). If typical mitosis were to occur during multiplication, it would be expected that resting cells with an interphase nucleus might be observed. Resting cells of $\boldsymbol{M}$. fulvus were not seen, however, except in the intermediate or fruiting body region. Cells in these areas are probably in the phase of negative growth acceleration or the stationary phase. There are several possibilities to account for the bilobed nucleus. It may be a binucleate cell which is dividing, and the division might be delayed, leading directly to the formation of two microcysts. Another possibility is that each lobe of the bilobed vegetative nucleus contains the $n$ number of chromosomes and that before going into the resting state the nucleus must acquire the $2 n$ number; this would, of course, be autogamy. Bilobed nuclei have also been reported in eubacteria. They were demonstrated in Escherichia coli and other organisms by Robinow (1947), in preparations of $E$. coli treated with ribonuclease by Tulasne \& Vendrely (1947), and were considered to be of sexual significance by Bisset (1950).

One of the authors (M.E.L.) is in receipt of a Predoctorate fellowship from the National Cancer Institute. Grateful acknowledgement is made to Mrs Hilda Daniels Agar for her assistance in electron microscopy. 


\section{REFERENCES}

Badian,J.(1930). Z cytologji miksobakteryj. Akta Polsk. Towarzystwa Botanicznego, $7,55$.

BeEbe, J. M. (1941). The morphology and cytology of Myxococcus xanthus n.sp. J. Bact. 42, 193.

Bisset, K. A. (1950). The Cytology and Life History of Bacteria. Baltimore: Williams and Wilkins Co.

Bisset, K. A. (1953). Bacterial cell envelopes. Sixth int. Congr. Microbiol. Rome.

Brieger, E. M., Cosslett, V. E. \& Glauert, A. M. (1954). Reproductive changes in avian tubercle bacilli studied with the electron microscope. J. gen. Microbiol. 10, 294.

Chapman, G. B. \& Hillier, J. (1953). Electron microscopy of ultra-thin sections of bacteria. I. Cellular division in Bacillus cereus. J. Bact. 66, 362.

Cosslett, V. E. (1948). Recent advances in electron microscopy in the United Kingdom. Research, 1, 293.

Delaporte, B. (1950). Observations on the cytology of bacteria. Advanc. Genet. $3,1$.

Fitz-JAmes, P. C. (1954). The duplication of bacterial chromatin. J. Bact. 68, 464.

Glauert, H. M. \& Brieger, E. M. (1955). The electron-dense bodies of Mycobacterium phlei. J. gen. Microbiol. 13, 310.

Grace, J. (1951). The life cycle of Sporocytophaga. J. gen. Microbiol. 5, 519.

Hillier, J., KNAYsi, G. \& BaKer, R. F. (1948). New preparation techniques for the electron microscopy of bacteria. J. Bact. 56, 569.

Hillier, J., Mudd, S. \& SMith, A. S. (1949). Internal structure and nuclei in cells of Escherichia coli as shown by improved electron microscopic technique. J. Bact. 57, 319.

KLIENEBerger-Nobel, E. (1945). Changes in the nuclear structure of bacteria particularly during spore formation. J. Hyg., Camb., 44, 99.

KuIENEBERger-NobeL, E. (1947). A cytological study of myxococi. J. gen. Microbiol. $1,33$.

Knaysi, G. (1951). Elements of Bacterial Cytology. Ithica, N.Y.: Comstock.

Knaysi, G., Hillier, J. \& Fabricant, C. (1950). The cytology of an avian strain of Mycobacterium tuberculosis studied with the electron and light microscope. J. Bact. 60, 423.

KNAYSI, G. \& MUDD, S. (1943). The internal structure of certain bacteria as revealed by the electron microscope. A contribution to the study of the bacterial nucleus. J. Bact. 45, 349.

Kunicki-GoldFinger, W.(1949). Budowa i cykl rozwojowy rodzaju Sporocytophaga Stanier. Ann. Univ. M. Curie-Sklodoreska (Section C. Biol.), 4, 396.

Muvo, S. (1953). The mitochondria of bacteria. J. Histochem. Cytochem. 1, 248.

Piekarski, G. (1939). Lichtoptische und übermikroskopische Untersuchungen zum Problem des Bakterienzellkerns. Zbl. Bkt. (I, Orig.), 144, 140.

Rosinow, C. F. (1944). Cytological observations on Bacterium coli, Proteus vulgaris and various aerobic spore-forming bacteria with special reference to the nuclear structures. J. Hyg., Camb. 43, 413.

RoBinow, C. F. (1947). Nuclear apparatus and cell structure of rod-shaped bacteria. Addendum in The Bacterial Cell; Dubos, R. J. Cambridge, Massachusetts: Harvard University Press.

Robinow, C. F. \& Cosslett, V. E. (1948). Nuclei and other structures of bacteria. J. appl. Physics, 19, 124.

Tulasne, R. \& Vendrely, R. (1947). Demonstration of bacterial nuclei with ribonuclease. Nature, Lond. 160, 225.

Winterscheid, L. C. \& MUdD, S. (1953). The cytology of the tubercle bacillus with reference to mitochondria and nuclei. Amer. Rev. Tuberc. 67, 59. 
Journal of General Microbiology, Vol. 16, No. 1

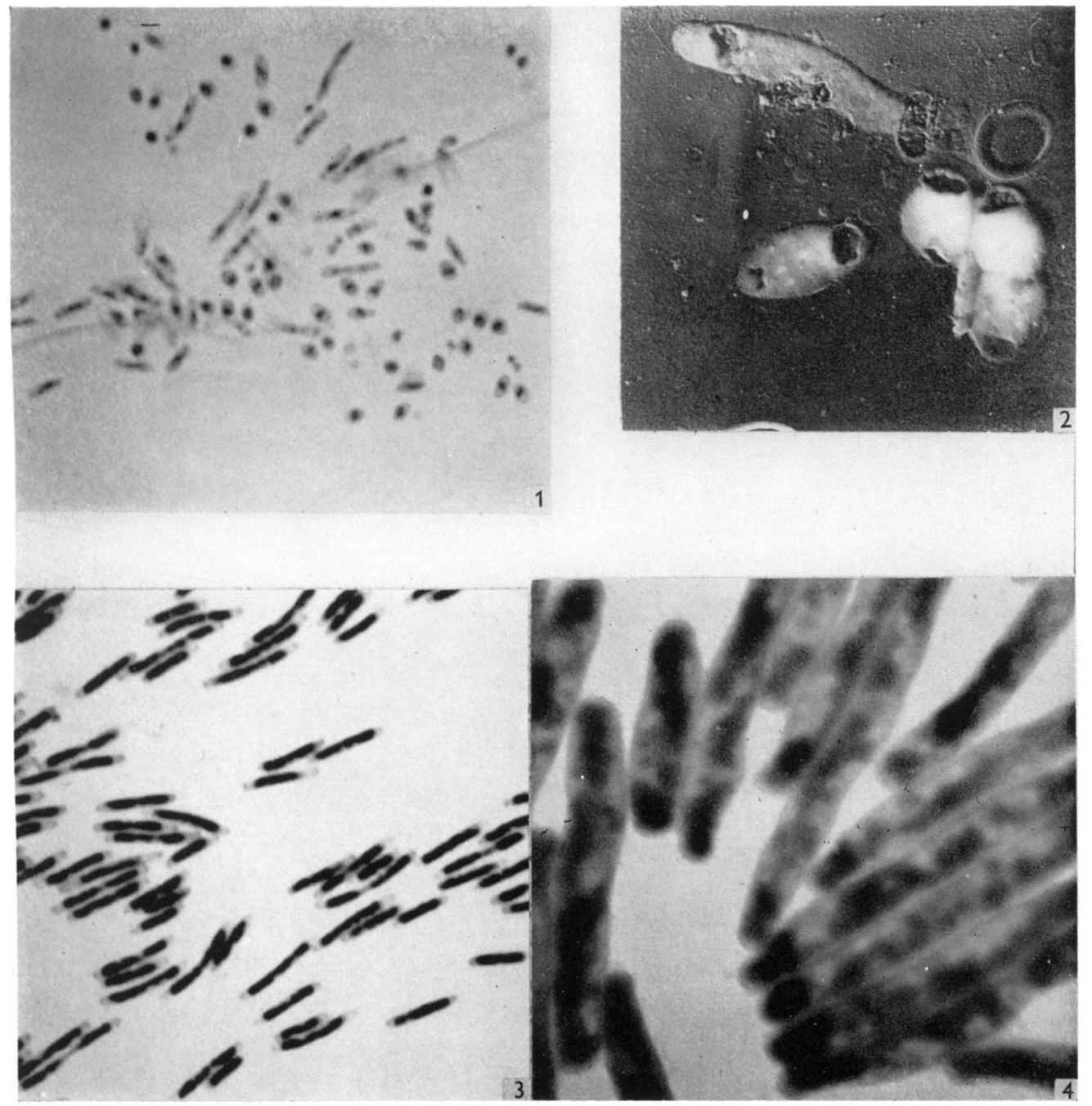

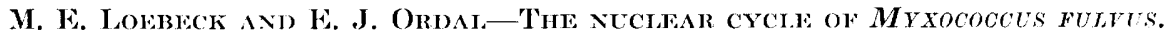
PIAT'TL 1 
Journal of General Microbiology, Vol. 16, No. 1

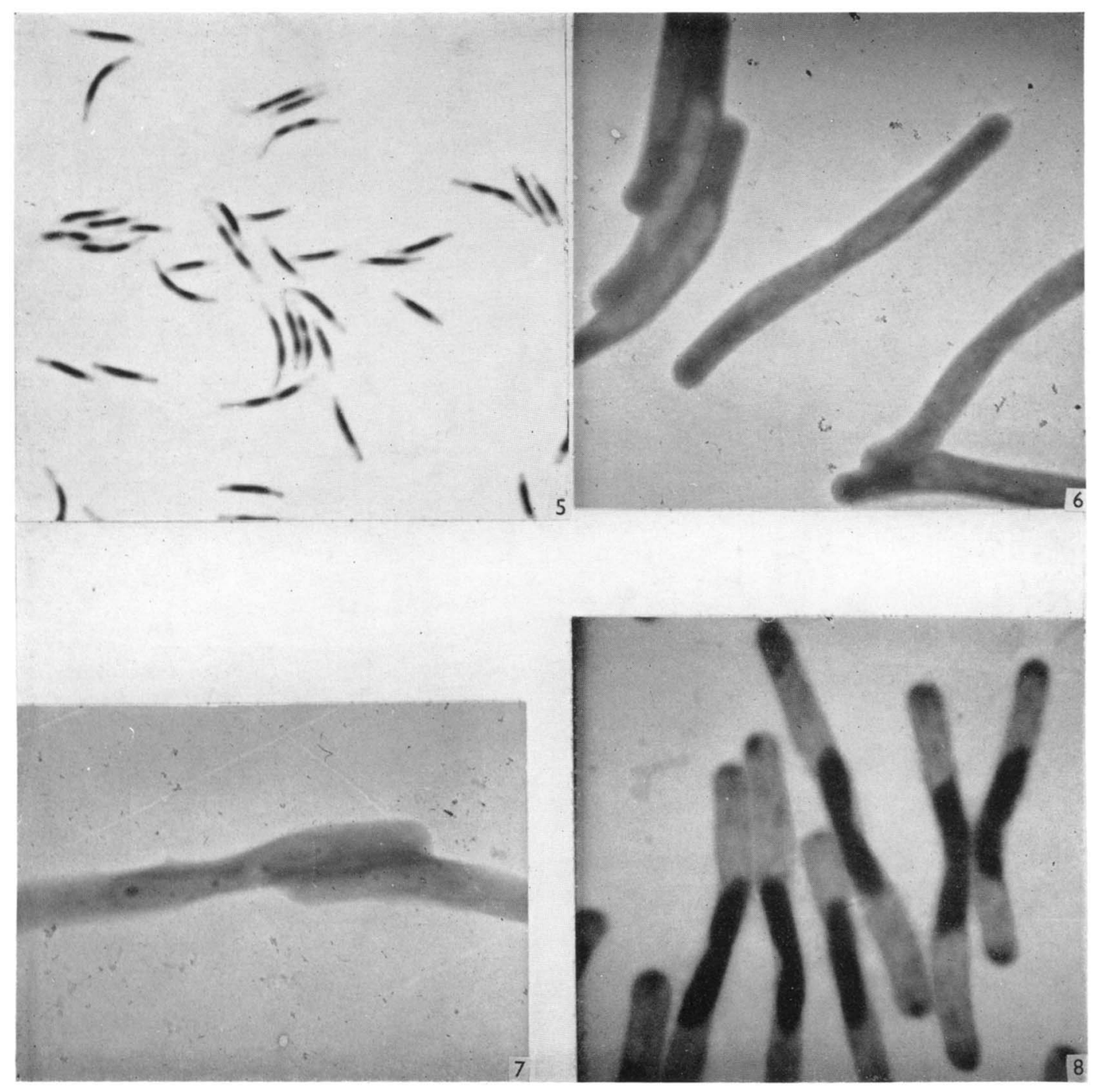

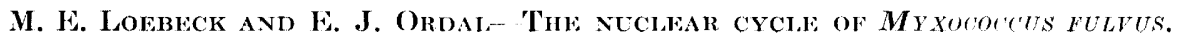
Platte 2 
Journal of General Microbiology, Vol. 16, No. 1

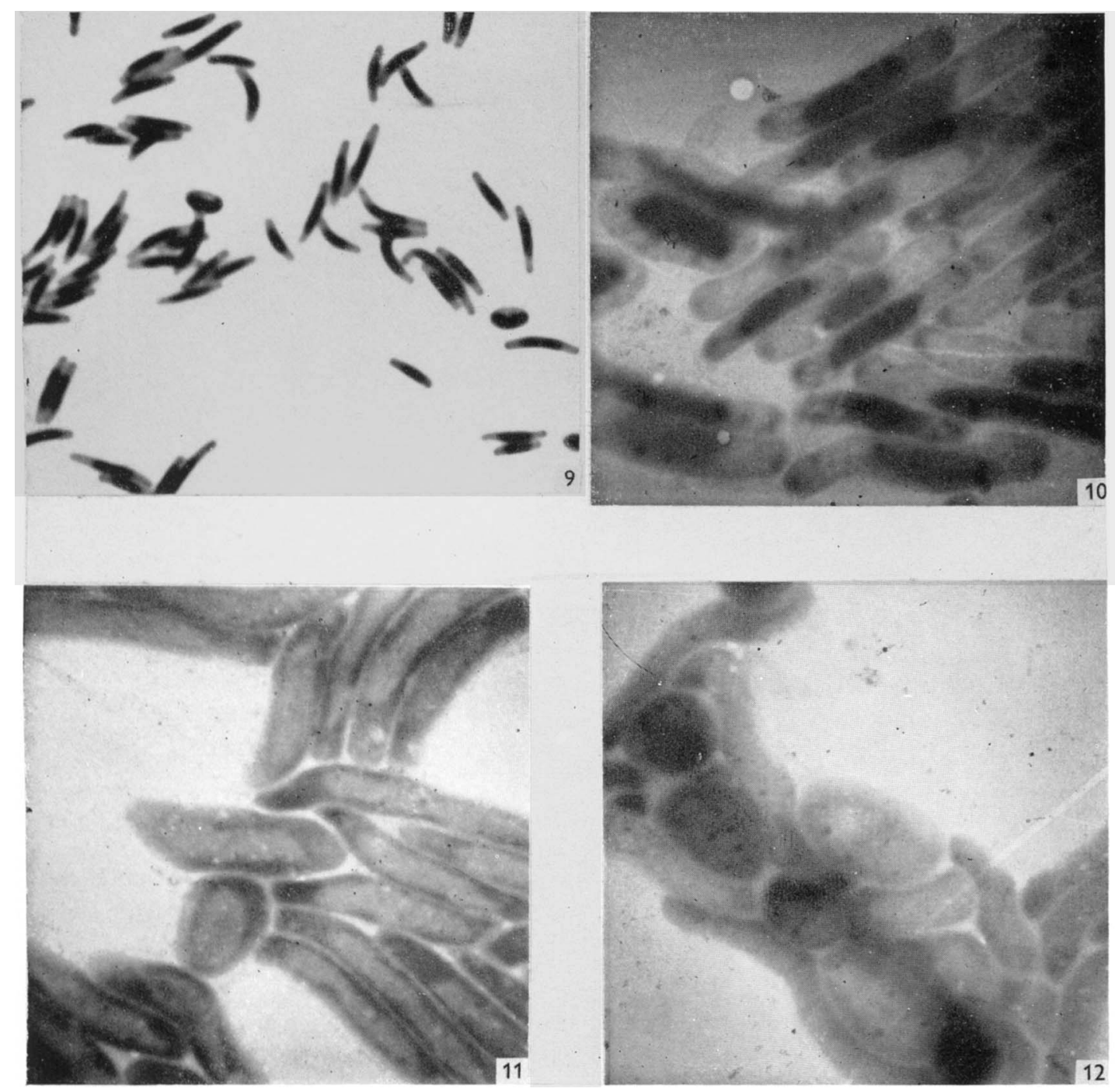

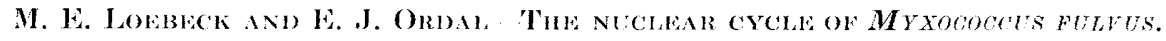
PLATL: : 
Journal of General Microbiology, Vol. 16, No. 1
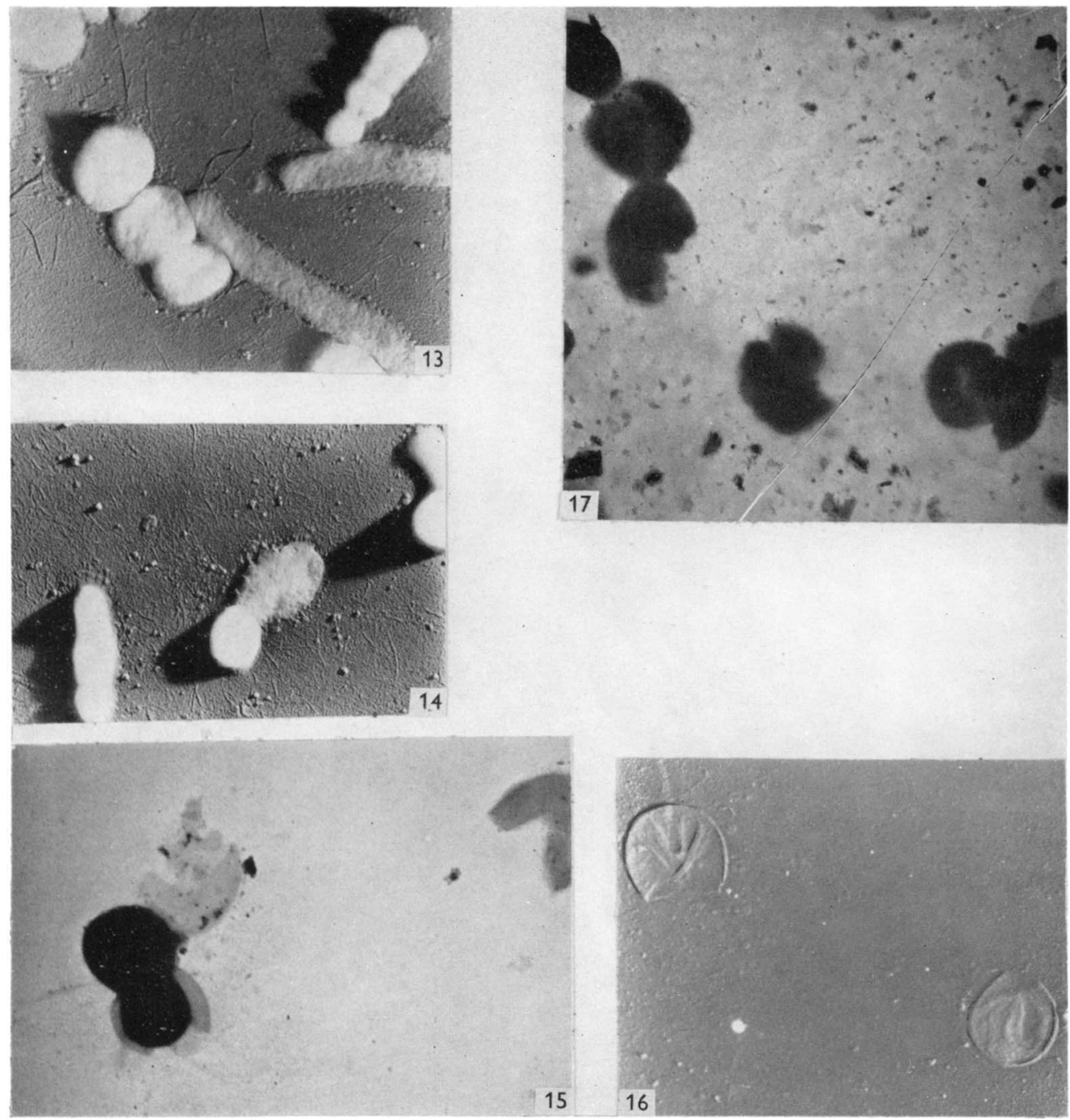

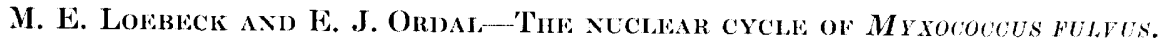
PIATe 4 
Journal of General Microbiology, Vol. 16, No. 1
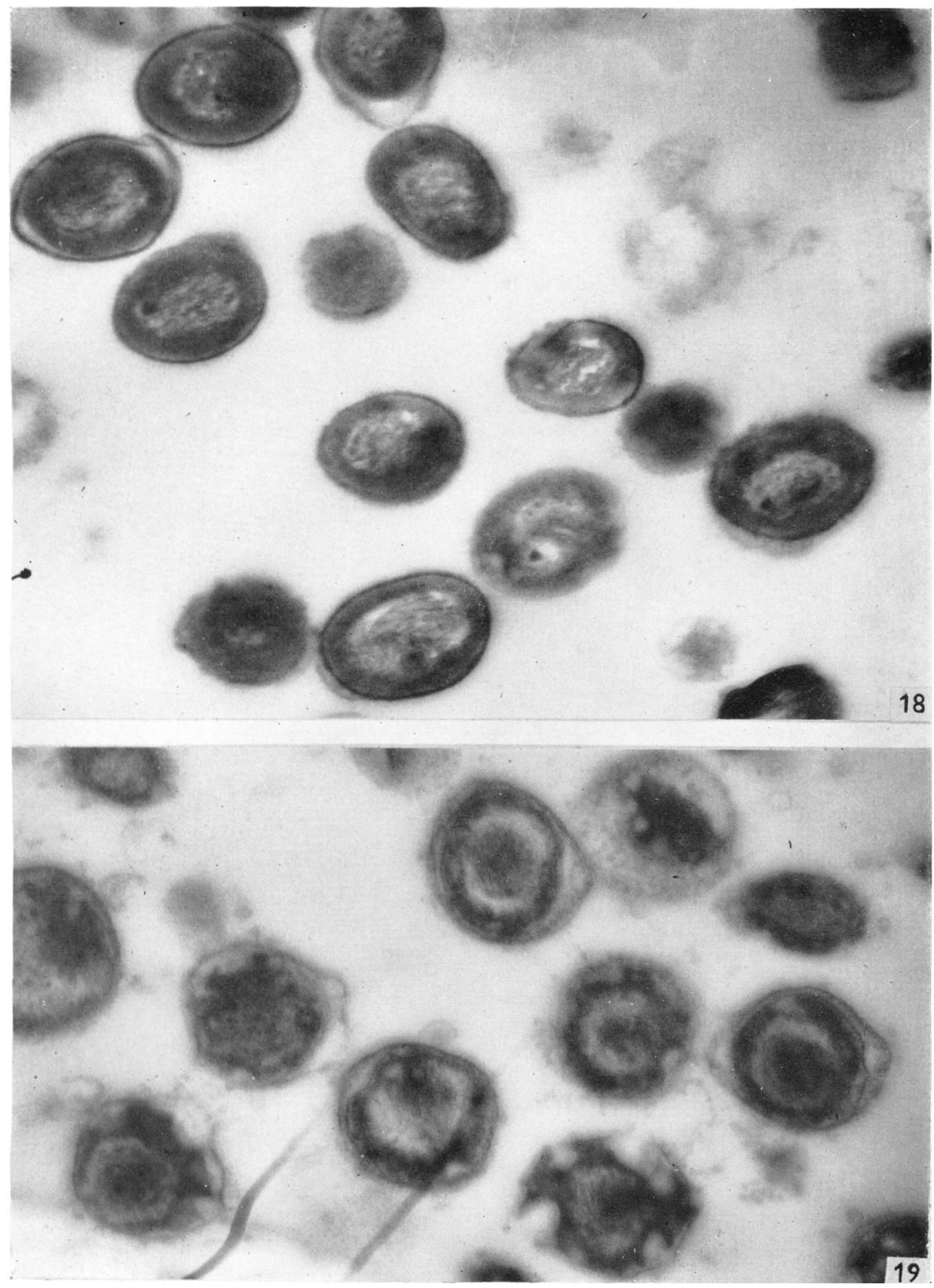

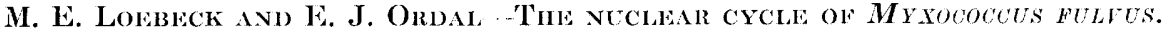
Plate 5 



\section{EXPLANATION OF PLATES}

\section{Plate 1}

Fig. 1. Germinating microcysts, treated with $\mathrm{HCl}$, followed by crystal violet. $\times 3000$.

Fig. 2. Germinating microcysts. Grown on dung agar for $5 \mathrm{hr}$. Picked up with collodion film. Ni shadowed. $\times 11,500$.

Fig. 3. Advancing swarm cells stained with Robinow-Giemsa method. $\times 3000$.

Fig. 4. Advancing swarm cells grown on collodion film over dung agar. Fixed with $\mathrm{OsO}_{4}$. $\times 11,500$.

\section{Plate 2}

Fig. 5. Intermediate cells by Robinow-Giemsa stain. $\times 3000$.

Fig. 6. Intermediate cells from 5-day culture. Formvar film over dung agar. $\mathrm{OsO}_{4}$ fixed. $\times 11,500$.

Fig. 7. Intermediate cells from 5-day culture. Formvar film over dung agar. Not fixed. $\times 11,500$.

Fig. 8. Intermediate cells from culture grown $2 \frac{1}{2}$ days on formvar film over dung agar. Not fixed. $\times 11,500$.

Plate 3

Fig. 9. Mature cells stained with Robinow-Giemsa stain. $\times 3000$.

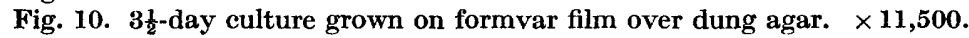

Fig. 11. Culture grown on formvar film over dung agar. Not fixed. $\times 11,500$.

Fig. 12. 5-day culture grown on formvar film over dung agar. Not fixed. $\times 11,500$.

\section{Plate 4}

Figs. 13, 14. Cells grown on dung agar, fixed with $\mathrm{OsO}_{4}$ in situ, picked up with formvar film and chromium shadowed.

Fig. 15. Shattered microcysts, fixed with $\mathrm{OsO}_{4} . \times 11,500$.

Fig. 16. Outer shell of microcyst. Ni shadowed. $\times 11,500$.

Fig. 17. Shattered inner shell. $\times 11,500$.

\section{Plate 5}

Figs. 18, 19. Ultra-thin sections of microcysts. $\times 28,000$. 